\title{
INEQUALITY IN THE INCOME OF THE POPULATION AS A DETERMINANT OF THE COUNTRY'S ECONOMIC GROWTH
}

\author{
Tamara Kocurová1, David Hampel ${ }^{1}$ \\ ${ }^{1}$ Department of Statistics and Operation Analysis, Faculty of Business and Economics, Mendel University in Brno, \\ Zemědělská 1, 61300 Brno, Czech Republic
}

Link to this article: https://doi.org/10.11118/actaun202068060987

Received: 22. 7. 2020, Accepted: 13. 11. 2020

To cite this article: KOCUROVÁ TAMARA, HAMPEL DAVID. 2020. Inequality in the Income of the Population as a Determinant of the Country's Economic Growth. Acta Universitatis Agriculturae et Silviculturae Mendelianae Brunensis, 68(6): 987-994.

\begin{abstract}
In this article, there is explored the dependence of economic performance and economic growth on income inequality expressed by Gini coefficient and S80/S20 ratio. Analysis is based on data collected upon EU countries in years 2007, 2012 and 2017. Cluster analysis points out to heterogeneity of EU countries in observed characteristics and enables creation of three groups of countries: postsocialistic, southern and northern. Regression analysis, which takes into account groups of countries, was used to assess and illustrate the dependence. The results show that income inequality has a negative impact on the country's GDP per capita, and its impact on economic growth differs for particular groups of countries.
\end{abstract}

Keywords: income inequality, Gini coefficient, GDP, economic growth, EU countries, regression analysis, cluster analysis, S80/S20 ratio

\section{INTRODUCTION}

Income inequality in connection with the economic level or economic growth has been an observed phenomenon for a long time. Kuznets (1955) researched the dependency of economic growth on income inequality. He worked with data about three developed countries (United States, United Kingdom, and Germany) to describe the relation. His conclusion is that rich and developed countries should be less unequal in terms of income. One of the main factors according to Kuznets is the process of industrialization. Firstly, the inequality will deepen which will be caused by lower number of workers switching from poor agriculture sector to the industrial one. However, the effect after some period should result in lower income inequality, since only minority of the population will still work in agriculture and therefore, the income will be distributed more evenly.
Currently, the problem of income inequality, including its relationship between economic level or growth, is being addressed by many experts. Probably Thomas Piketty is currently dealing most intensively with the issue of income inequality. In his work "The Kuznets Curve: Yesterday and Tomorrow", Piketty (2006), he follows the work of Simon Kuznets, who, among other issues, dealt with the long-term development of income inequality. Piketty partially contradicts Kuznet's interpretation and offers an alternative explanation. Piketty also conducted studies comparing inequality in developed countries (Piketty and Saez, 2006). In his book "Capital in the Twenty-First Century", Piketty focuses on wealth and income inequality in Europe and the United States since the $18^{\text {th }}$ century. The main idea of this book is that inequality is not a coincidence, but rather a feature of capitalism that can only be changed by state intervention (Piketty, 2013). 
We follow some ideas of Piketty, and more specifically we are interested in the possible effect of income inequality on economic growth and economic level. There is no doubt that adequate economic growth is a desirable situation in each country because it brings among other benefits lower unemployment, lower government borrowing, improved public services or increased research and development. If it were possible to prove that a certain setting of income inequality has a positive effect on economic growth, it would be possible to influence income inequality by the government (at least to some extent) and thus achieve higher economic growth.

The question remains to what extent income inequality is positive and becomes a motivating factor for the population. Determining this limit is very difficult, and that is where the disagreement arises. However, most opinions clearly agree in the case of extreme values. If income inequality is too high, it certainly has a negative or demotivating effect on people's productivity, which is also related to the subsequent (lower) economic growth of the country. According to Luca Visentini, general secretary of the European Trade Union Confederation, income inequality has another reason that is holding back the economy. He argues that public budgets must be spent on balancing the income levels of people in financial distress for various reasons, so inequality results in a reduction in public resources for potential investment, which in turn reduces the country's growth potential (Seetharaman and Kan, 2018).

However, income inequality can be perceived in two ways. On the one hand, there is inequality within a given country, but it is also important for inequality between individual countries of a certain area, e.g. European Union. In this work, inequality within individual countries will be further addressed, but also inequality between individual countries of a certain area, e.g. European Union is important. If the income in a country is at a very low level (compared to other countries), a large percentage of people will move for a higher income and thus improve their standard of living. Migration can have positive as well as negative effects for both countries, for example due to the transfer of funds earned in a higher-income country to a poorer one.

Keeley (2015) describes that income inequality began to decline from 1920-1930 (in some countries a little later, around the 50s). This trend was positive, but in 1970-80 the trend turned around, which means that income inequality began to increase again. In 2017, within the European Union, 38.6\% of disposable income was distributed to $20 \%$ of the highest-income people, with the bottom quintile (20\% of the lowest-income people) accounting for only $7.8 \%$ of total income this year (Eurostat, 2020). In United States of America, however, inequality is far higher than in European countries.
The Statista portal (2020) states that people in the top quintile earn $51.5 \%$ of total income and people in the bottom quintile earn only $3.1 \%$. The gap in income inequality in the United States and the EU is therefore relatively high.

One of the problematic effects of income inequality is also social exclusion or isolation. This may be due to the categorization of people based on the income group in which they are located. Socially weaker people are more likely to have various mental health problems and addictions. Other consequences include educational attainment, susceptibility to violent acts, or the birth rate at a younger age. Unfortunately, all this exacerbates the bad situation, as well as income inequality. The state is therefore trying to balance the situation by various means. For example, the state provides unemployment benefits, benefits in material need, housing allowances, maternity benefits, or various types of pensions (disability, widow's, orphan's). Specifically in Slovakia, from September 2019, lunches for all primary school students will be free (subsidized by the state). Tuition fees are also introduced in some countries for explicitly socially disadvantaged families.

Problems related to well-being and sustainable economic growth are also affected by distribution of population income. In Kabát et al. (2014), Střelec et al. (2014) and Hampel et al. (2016) wide range of alternative approaches and measures of economic growth sustainability are presented including income inequality with emphasis on share of people under poverty line.

The aim of this paper is to verify the possible dependence between the economic power resp. the extent of the country's economic growth and the income inequality in the countries of the European Union.

\section{MATERIALS AND METHODS}

As the indicator of income inequality is chosen the Gini coefficient and the indicator S80/S20. Both indicators show the degree of inequality, but the Gini coefficient takes into account the full size of the population, while the S80/S20 coefficient covers only $20 \%$ of the richest and poorest people. Both indicators, sourced from the Eurostat database for the years 2007, 2012 and 2017, are based on EU statistics on income and living conditions (EUSILC) survey. The gross domestic product per capita, expressed in units of the purchasing power standard (PPS), is used to express economic power. PPS is used to eliminate differences between the different price levels of countries. For the purposes of this work, the economic growth of the country will be calculated as the ratio of GDP per capita for two consecutive years, e.g. for 2007 it will be the ratio of GDP in 2006 and 2007, multiplied by 100. Data for 28 countries of the European Union in the years 2007-2017 are obtained from the Eurostat database. 
The above-mentioned data will be analysed as cross-sectional using a regression analysis, which was chosen to determine the dependence of economic strength and growth of the country $j$, $j=1, \ldots, 28$, on income inequality. Basic models, which describe the dependence of GDP per capita (GDPpc) on the Gini coefficient resp. indicator S80/S20 in selected year $t, t \in\{2007,2012,2017\}$ are of the form

$$
G D P p c_{j t}=\beta_{0}+\beta_{1} \operatorname{Gini}_{j t}+\varepsilon_{j t}
$$

resp.

$$
G D P p c_{j t}=\beta_{0}+\beta_{1} S 80 / S 20_{j t}+\varepsilon_{j t}
$$

or the dependence of economic growth $(\triangle G D P p c)$ on the Gini coefficient resp. indicator $S 80 / S 20$ of the form

$\triangle G D P p c_{j t}=\beta_{0}+\beta_{1} \operatorname{Gini}_{j t}+\varepsilon_{j t}$

resp.

$$
\Delta G D P p c_{j t}=\beta_{0}+\beta_{1} S 80 / S 20_{j t}+\varepsilon_{j t}
$$

Extended models, where countries are divided into similar groups using cluster analysis, are given as

$$
G D P p c_{j t}=\beta_{1}+\sum_{i=2}^{k} \beta_{i} D_{i}+\alpha_{1} \operatorname{Gini}_{j t}+\sum_{i=2}^{k} \alpha_{i} D_{i} \operatorname{Gini}_{j t}+\varepsilon_{j t}
$$

resp.

$$
\begin{aligned}
G D P p c_{j t}= & \beta_{1}+\sum_{i=2}^{k} \beta_{i} D_{i}+\alpha_{1} S 80 / S 20_{j t}+ \\
& +\sum_{i=2}^{k} \alpha_{i} D_{i} S 80 / S 20_{j t}+\varepsilon_{j t}
\end{aligned}
$$

or

$\Delta G D P p c_{j t}=\beta_{1}+\sum_{i=2}^{k} \beta_{i} D_{i}+\alpha_{1} \operatorname{Gini}_{j t}+\sum_{i=2}^{k} \alpha_{i} D_{i} \operatorname{Gini}_{j t}+\varepsilon_{j t}(7)$

resp.

$$
\begin{aligned}
\Delta G D P p c_{j t}= & \beta_{1}+\sum_{i=2}^{k} \beta_{i} D_{i}+\alpha_{1} S 80 / S 20_{j t}+ \\
& +\sum_{i=2}^{k} \alpha_{i} D_{i} S 80 / S 20_{j t}+\varepsilon_{j t},
\end{aligned}
$$

where $D_{i}$ means the vector dummy variable for $i$-th countries group, $i=1, \ldots, k$ and $D_{i}$ is equal to 1 for countries included in the group $i, 0$ otherwise; $D_{i}$ Gini resp. $D_{i} S 80 / S 20$ means vector created by multiplying corresponding elements of $D_{i}$ and Gini resp. $D_{i}$ and S80/S20. Parameters of proposed regression models were estimated by the ordinary least squares method. Classical assumptions of estimated linear model were checked (note that these assumptions were fulfilled in all cases).

For establishing groups of similar countries we use hierarchical cluster analysis separately for the years 2007, 2012 and 2017, always on the basis of two values: The first value will reflect economic strength or growth through GDP per capita and its year-on-year growth. The second value will be income inequality in the country, reflected by the Gini coefficient or the S80/S20 indicator. Computational system MATLAB R2019b is used for all calculations and significance level is set to 0.05 .

\section{RESULTS}

Possible relationships between GDP resp. GDP growth and income inequality represented by Gini coefficient resp. S80/S20 indicator are illustrated in Fig. 1; note that Luxembourg is omitted according to relatively high GDPpc; Gini as well as S80/S20 is missing for Croatia in 2007 and Ireland is omitted in model for the year 2017 because of relatively high $G D P p c$. It is visible indirect dependency of GDP on income inequality, whereas for GDP growth we can assume independency. Further, using Gini or S80/S20 indicator leads to very similar graphs, what is - with one exception - true for all investigated models.

Cluster analysis was performed based on several distances between objects and several clustering methods. Euclidean distance between countries followed by the Ward method clusters creation was selected as the most appropriate because of high degree of geographical and historical similarity of grouped countries. Particular countries groups constructed with given variables in particular years were assessed and overall division of countries was established:

- Post-socialistic countries and Malta - Bulgaria, the Czech Republic, Estonia, Croatia, Lithuania, Latvia, Hungary, Malta, Poland, Romania, Slovakia, Slovenia;

- Southern countries - Cyprus, France, Greece, Portugal, Spain, Italy;

- Northern countries - Belgium, Denmark, Finland, the Netherlands, Ireland, Luxembourg, Germany, Austria, United Kingdom, Sweden.

Note that Malta has different history than postsocialistic countries, but it fits to this group much better than among the southern countries.

The first key result is that the division of countries into groups has proved to be particularly important in terms of individual models. Dependencies after the division are more often significant and coefficient of determination increased rapidly. For comparison: the model examining the dependence of GDP per capita on the Gini coefficient for 2012 without the division of countries has a coefficient of determination of only $25 \%$, while the same model with the distribution of countries explained $90 \%$ of variability.

From the point of view of the country's economic strength, the dependence appears to be the same for all three groups of countries i.e. the higher the income inequality, the lower the economic power of the country. The slope of particular regression lines does not differ significantly, but constants of southern group as well as for northern group 

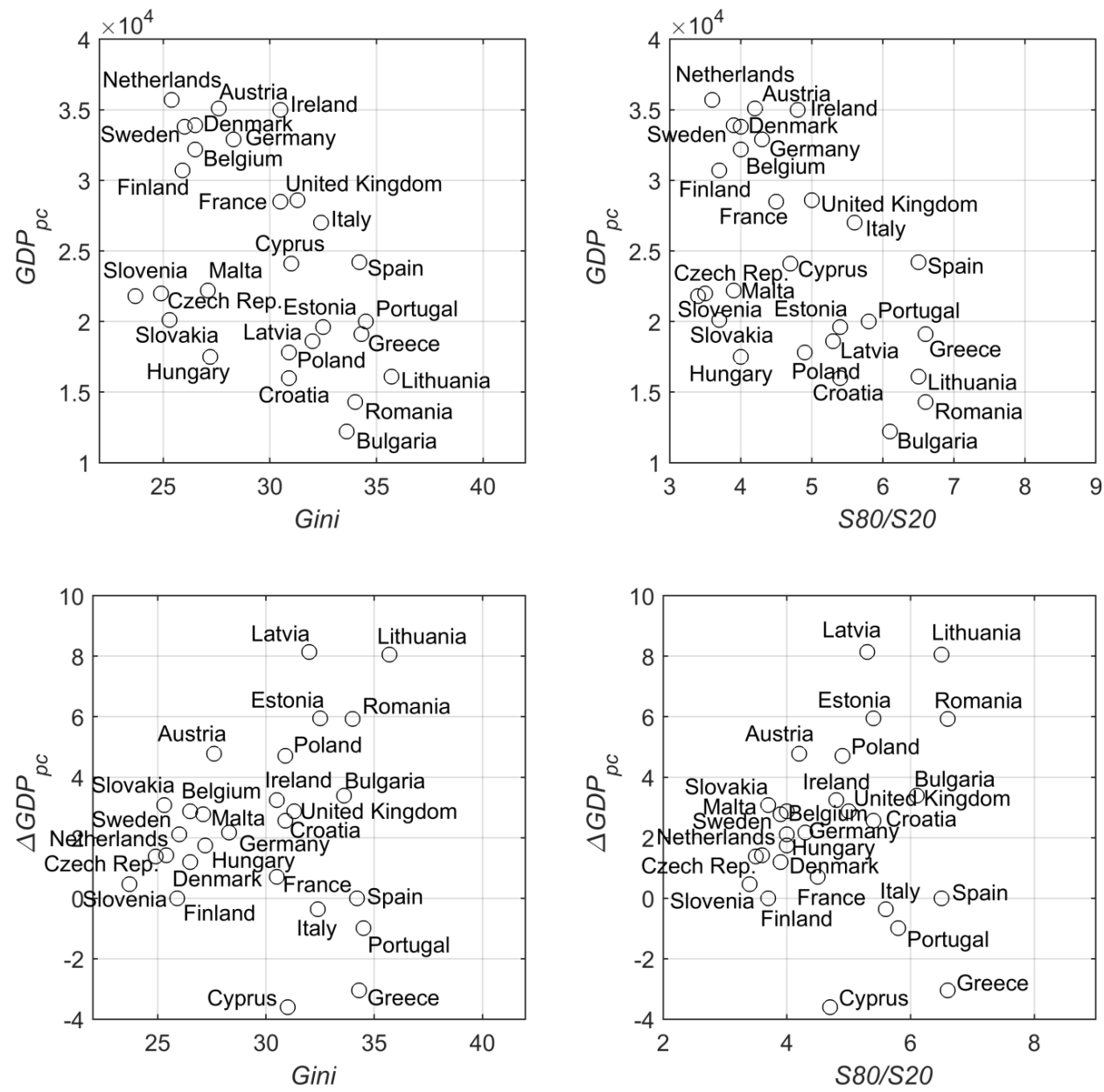

1: Dot diagrams of investigated variables in the year 2012

I: Estimated parameters, related p-values and adjusted coefficients of determination for selected models (for models we are dealing with lower). By 'NS' we denote insignificant parameters, which were eliminated from the model based on descending elimination. Parameter $\beta_{2}$ and variable $D_{2}$ Gini relate to the group of southern countries, parameter $\beta_{3}$ and variable $D_{3}$ Gini to the group of northern countries. Group of post-socialistic countries is included in constant and Gini variable. Analogically, the last column uses S80/S20 instead Gini.

\begin{tabular}{lcccccccc}
\hline Dep. var. GDPpc 2007 & GDPpc 2012 & GDPpc 2017 & 2007 & 2012 & 2017 & dep. var. & 2007 \\
\hline constant & 31429 & 37455 & 36216 & -8.6747 & -10.908 & 5.0328 & constant & 3.8522 \\
\hline$\beta_{2}$ & $\begin{array}{c}10114 \\
(<0.001)\end{array}$ & $\begin{array}{c}7572.4 \\
(<0.001)\end{array}$ & $\begin{array}{c}4914.9 \\
(0.006)\end{array}$ & $\begin{array}{c}23.089 \\
(0.038)\end{array}$ & $\mathrm{NS}$ & $\mathrm{NS}$ & $\beta_{2}$ & $\mathrm{NS}$ \\
\hline$\beta_{3}$ & $\begin{array}{c}14830 \\
(<0.001)\end{array}$ & $\begin{array}{c}13455 \\
(<0.001)\end{array}$ & $\begin{array}{c}12827 \\
(<0.001)\end{array}$ & $\begin{array}{c}23.689 \\
(0.012)\end{array}$ & $\mathrm{NS}$ & $\mathrm{NS}$ & $\beta_{3}$ & $\mathrm{NS}$ \\
\hline Gini & -490.92 & $\begin{array}{c}-646.36 \\
(<0.001)\end{array}$ & $\begin{array}{c}-467.43 \\
(0.009)\end{array}$ & $\begin{array}{c}0.65657 \\
(<0.001)\end{array}$ & $\begin{array}{c}0.49206 \\
(<0.001)\end{array}$ & $\mathrm{NS}$ & $\mathrm{S} 80 / \mathrm{S} 20$ & $\begin{array}{c}1.5020 \\
(0.002)\end{array}$ \\
\hline \multirow{2}{*}{$\mathrm{D}_{2}$ Gini } & $\mathrm{NS}$ & $\mathrm{NS}$ & $\mathrm{NS}$ & $\begin{array}{c}0.95088 \\
(0.009)\end{array}$ & $\begin{array}{c}-0.19762 \\
(<0.001)\end{array}$ & $\begin{array}{c}-0.08050 \\
(0.0011)\end{array}$ & $\mathrm{D}_{2} \mathrm{~S} 80 / \mathrm{S} 20$ & $\begin{array}{c}-1.3227 \\
(<0.001)\end{array}$ \\
\hline \multirow{2}{*}{$\mathrm{D}_{3}$ Gini } & $\mathrm{NS}$ & $\mathrm{NS}$ & $\mathrm{NS}$ & $\begin{array}{c}-0.99943 \\
(0.004)\end{array}$ & $\mathrm{NS}$ & $\begin{array}{c}-0.08869 \\
(<0.001)\end{array}$ & $\mathrm{D}_{3} \mathrm{~S} 80 / \mathrm{S} 20$ & $\begin{array}{c}-1.1503 \\
(<0.001)\end{array}$ \\
\hline $\mathrm{R}_{\text {adi }}^{2}$ & 0.88 & 0.90 & 0.80 & 0.71 & 0.72 & 0.43 & $\mathrm{R}_{\text {adi }}^{2}$ & 0.65 \\
\hline
\end{tabular}

significantly differs from constant of post-socialistic group in 2007 and 2012; in 2017 it is true after removing Luxembourg as an outlier. Resulting regressions are depicted in Fig. 2. The models where
S80/S20 indicator was used instead of the Gini coefficient were very similar, while the monotony of the lines was maintained in all cases. 
Within this analysis, however, the position of groups of countries in relation to each other is particularly interesting. In 2007, the values of the southern and northern countries were relatively close, while the post-socialist countries lagged (in terms of GDP). However, this distribution changed until 2012, when the distance between the northern and southern countries widened, creating a very similar gap between the southern and northern countries and between the southern and post-socialist countries. In the last year of the period under review (2017), the position of the groups changed again. With their GDP growth, post-socialist countries moved even closer to the southern ones, but the northern ones (also thanks to higher GDP) moved away again.

Impact of income inequality on economic growth is not so clear as in the case of GDP level. When using
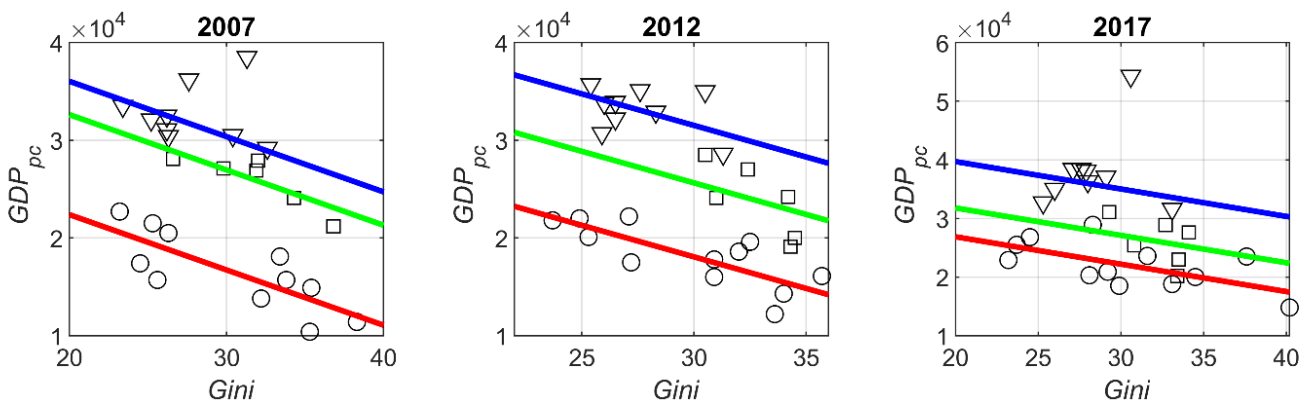

2: Estimated regression lines given by extended models for GDPpc. The red line shows the dependence within the post-socialist countries and Malta (individual countries represented by circles), the green line reflects the southern countries (squares) and the blue line the northern countries (triangles).
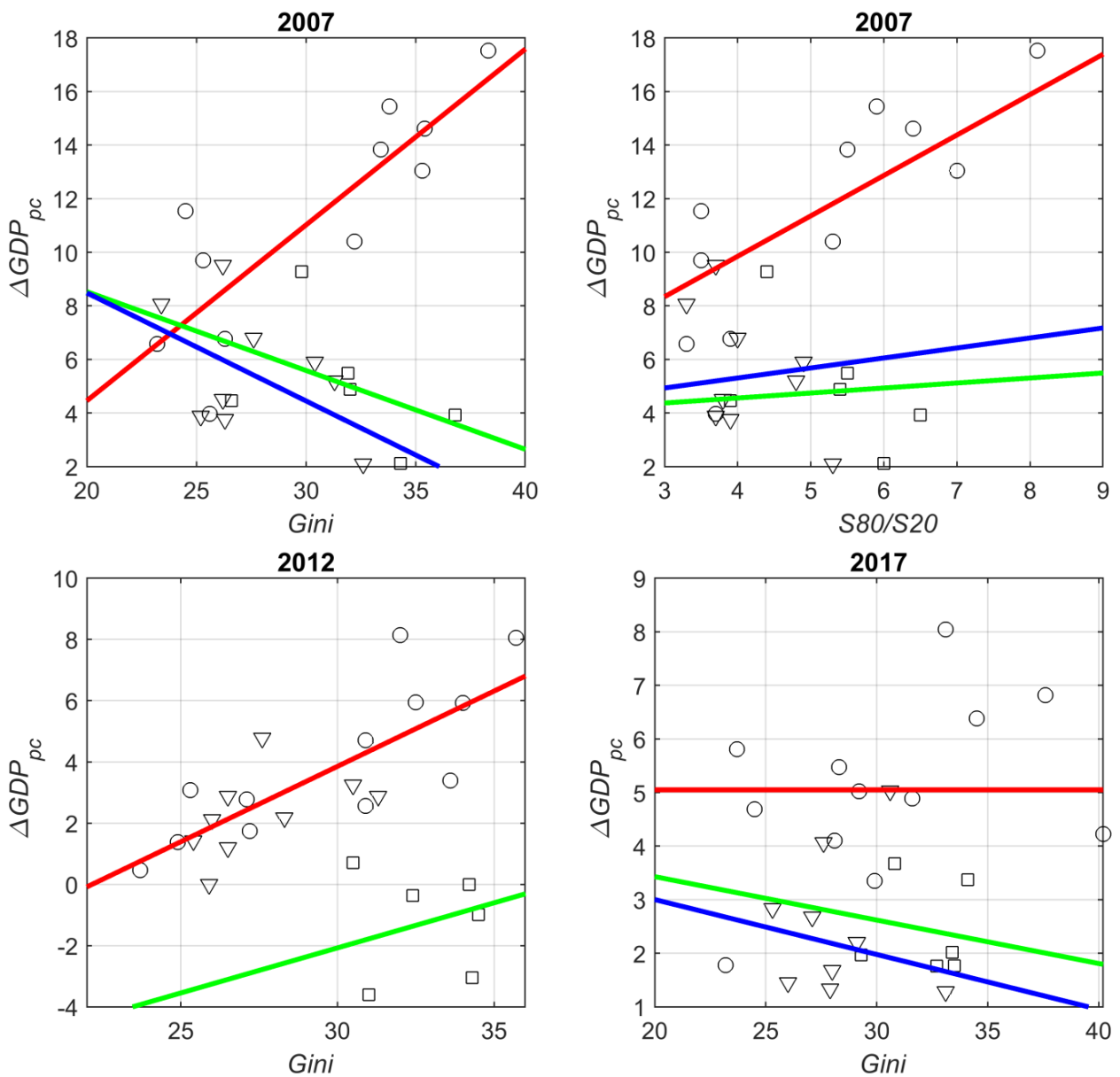

3: Estimated regression lines given by extended models for $\triangle G D P_{p c}$. The red line shows the dependence within the post-socialist countries and Malta (individual countries represented by circles), the green line reflects the southern countries (squares) and the blue line the northern countries (triangles). 
the basic models (without division into groups), the dependencies were indescribable in a relevant way. However, when applying the extended models with respect to individual groups, interesting results were obtained, see Fig. 3. In 2007, the dependence of growth on inequality in the case of post-socialist countries appears to be significant with positive slope. For the southern and northern countries, the results are not clear in a given year, because when using the Gini coefficient, the analysis indicates a negative dependence and in the case of the S80/S20 coefficient a neutral to slightly positive one. In the year 2012, post-socialist and northern countries merged into one group. Both indicators of income inequality in this year show a positive effect on this common group, but also on the southern countries, as the economic growth of the countries increases with increasing inequality. In the analysis for the year 2017, the impact of income inequality in the case of southern and northern countries appears to be negative. In the case of post-socialist countries, however, its impact was positive (using the S80/S20 coefficient) or neutral (using the Gini coefficient).

\section{DISCUSSION}

Experts have differing views on the consequences of income inequality. Some argue that income inequality needs to be reduced by various means, but others see it as a driver of economic growth. There are also economists who are aware that there is a threshold beyond which inequality is satisfactory, but when it is exceeded, it becomes harmful, so it is necessary to find "optimal" inequality level. Freeman (2012) states that after crossing this imaginary boundary, economic growth declines with growing inequality. Inequality in that case will be motivating only for a very small number of individuals with a suitable background, who will participate in economic growth. The frustrated majority of the population, on the other hand, will stagnate with the knowledge of the impossibility of obtaining a higher income.

However, based on this work, inequality with regard to the country's production appears to be an unfavourable factor. With increasing inequality, a declining trend in GDP per capita can be seen within the European Union. As a result, it seems to be appropriate to reduce income inequality (at least to boost production).

There are several possible ways to achieve lower income inequality. Novotný (2006) sees the potential for elimination of income inequality in redistribution measures, especially at the intercountry level. According to him, the only direct tool of this type is development aid. However, there are other ways (albeit indirect) such as international trade and investment, migration, or the effects of technological progress. However, Novotný's (2006) solutions focus on inequality between countries and not on inequality between people within a country. Marion (2015) proposes to solve the problem of inequality through the equal rights of women and their promotion in job positions. He claims that about $60 \%$ of poor people are women, only half of whom are active workers. If developing countries were more inclusive of women, they could provide a huge base of labour, resulting in income and subsequent consumption that would support the country's economic growth. Keeley (2015) believes that state intervention is needed to reduce income inequality and that this is especially true in three areas - education, jobs and taxes and levies.

Carlén (2017) describes the five main measures that should reduce inequality. Gender equality is also part of its solution, which agrees with Marion (2015). However, according to Carlén (2017), the first solution is to reduce growing social and economic disparities. He proposes to eliminate them by higher taxes on capital, financial services, and the highest incomes. Another way is to support educational opportunities for all people. As one of the solutions, Carlén (2017) also considers strengthening the influence and responsibility of the social partners. As a result, the number of conflicts in the labour market should be reduced. Carlén's latest proposed solution is a global agreement for equality and inclusive growth. He points out that even within trade unions, employees have a better chance of achieving results if trade unions from different countries are involved in certain matters.

Gründler and Scheuermeyer (2018) are also of the opinion that income inequality affects the country's economy. They claim that countries (companies) with high inequality usually have less educated people, higher birth rates and lower investment value. These consequences are particularly noticeable in times of high interest rates when people on lower incomes do not have the opportunity to cover the income gap with the wealthier population. Gründler and Scheuermeyer (2018) also argue that in developing countries, on the contrary, income inequality can have an appropriate effect on its economic growth.

The view of the chairman of the Czech-Moravian Confederation of Trade Unions, Josef Středula, is interesting as well (see Tưma, 2017). He disagrees with the thesis that income inequality is beneficial in general; according to him, the facts that prove it are questionable. He cites the 2015 statistics as an example, while in Scandinavia the income of people in the upper decile was five to six times higher than in the lower decile. This value was 5.4 in the Czech Republic. Inequality values are therefore at a similar level, but the notes that the quality of life in Scandinavia is generally considered to be the highest. The inhabitants of the Czech Republic should therefore have a happy life based on income inequality statistics, but the reality is really different. This is mainly due to wages that are at a quite low level compared to abroad. 
However, there are also opinions that income inequality has in some cases no impact on productivity and economic growth, respectively does not affect them in any way. For example, Kelley and Evans (2017) arrived to argue that income inequality has a neutral impact in progressive countries. On the other hand, they admit negative influence of income inequality under certain conditions and in certain companies.

\section{CONCLUSION}

It can be concluded that income inequality emerged as a negative factor influencing the level of GDP. The impact on economic growth cannot be described uniformly, but in the case of post-socialist countries and Malta it is positive. Thus, income inequality acts as a motivating factor or driving force in countries with relatively lower GDP level.

For business companies operating in countries with cheap labour, which have benefited from relative income inequality between countries, is growing inequality becoming a threat. Low wages compared to the remaining countries, together with possibility of labour migration, will cause an outflow of potential employees willing to work under the current unfavourable conditions. Also, relatively high inequalities within a country can be dangerous for companies as well, especially due to a shortage of skilled workers (caused by lower educational attainment for people from lowincome families). However, income inequality can have a positive impact in the case of highly rated positions, where it can be motivating.

Further research in relation of income inequality and economic output or its growth can be focused on extension of set of countries (for example panel data analysis in Dabla-Norris et al., 2015), where limiting factor is availability and quality of income inequality measures. Another direction can be focusing on effectivity assessment techniques as in Issever Grochová et al. (2014) and Hampel et al. (2016), where DEA method is employed for alternative evaluation of economical sustainability and well-being.

Acknowledgements

This article was supported by the grant No. PEF/TP/2020002 of the Internal Grant Agency PEF MENDELU.

\section{REFERENCES}

CARLÉN, T. 2017. Inequality is bad for business - a progressive agenda for equality. The Swedish Trade Union Confederation.

DABLA-NORRIS, E., KOCHHAR, K., SUPHAPHIPHAT, N., RICKA, F. and TSOUNTA, E. 2015. Causes and Consequences of Income Inequality: A Global Perspective. International Monetary Fund.

EUROSTAT 2020. Living conditions in Europe - income distribution and income inequality. Eurostat. [Online]. Available at: https://ec.europa.eu/eurostat/statistics-explained/index.php/ Living_conditions_in_Europe_-_income_distribution_and_income_inequality\#Income_inequality [Accessed: 2020, July 10].

FREEMAN, R. B. 2012. Optimal inequality for economic growth, stability and shared prosperity: the economics behind the Wall Street Occupiers Protest? Insights - Melbourne Business and Economics, 11: $5-11$.

GRÜNDLER, K., SCHEUERMEYER, P. 2018. Growth effects of inequality and redistribution: What are the transmission channels? Journal of Macroeconomics, 55: 293-313.

HAMPEL, D., ISSEVER GROCHOVÁ, L., JANOVÁ, J., KABÁT, L. and STŘELEC, L. 2016. Sustainable Development in the EU. In: Competitiveness, Social Inclusion and Sustainability in a Diverse European Union: Perspectives from Old and New Member States. Springer Switzerland.

ISSEVER GROCHOVÁ, L., JANOVÁ, J., HAMPEL, D. and STŘELEC, L. 2014. Alternative approach of assessing European countries efficiency from the perspective of sustainable economic performance. In: Proceedings of $32^{\text {nd }}$ International Conference Mathematical Methods in Economics. Olomouc: Univerzita Palackého v Olomouci.

KABÁT, L., HAMPEL, D., ISSEVER GROCHOVÁ, L., JANOVÁ, J. and STŘELEC, L. 2014. Alternative approaches for assessing the European countries economic and social results. Procedia Economics and Finance, 12: 273-282.

KEELEY, B. 2015. Income Inequality: The Gap between Rich and Poor. OECD Publishing.

KELLEY, J. and EVANS, M. D. R. 2017. The new income inequality and well-being paradigm: Inequality has no effect on happiness in rich nations and normal times, varied effects in extraordinary 
circumstances, increases happiness in poor nations, and interacts with individuals' perceptions, attitudes, politics, and expectations for the future. Social Science Research, 62: 39-74.

KUZNETS, S. 1995. Economic Growth and Income Inequality. American Economic Review, 45(1): 1-28. MARION, D. 2015. Why inequality is bad for business. The Borgen Project. [Online]. Available at: https://borgenproject.org/inequality-bad-business/ [Accessed: 2020, July 10].

NOVOTNÝ, J. 2006. Negativní vlivy společensko-ekonomických nerovností a mechanismy jejich regulace: argumenty z rozvojových zemí. Ekonomický časopis, 54(7): 709-724.

PIKETTY, T. 2006. The Kuznets Curve: Yesterday and Tomorrow. Oxford University Press.

PIKETTY, T. and SAEZ, E. 2006. The Evolution of Top Incomes: A Historical and International Perspective. American Economic Review, 96(2): 200-205.

PIKETTY, T. 2013. Capital in the Twenty-First Century. Cambridge, MA and London, England: Harvard University Press.

SEETHARAMAN, M. and KAN, C. 2018. Europe's Ticking Time Bomb: Wage Inequalit. [Online]. Available at: https://www.euronews.com/2018/06/12/europe-s-ticking-time-bomb-wage-inequality [Accessed 2020-07-10].

STATISTA. 2020. Shares of household income of quintiles in the United States from 1970 to 2017. Euronews. [Online]. Available at: https://www.statista.com/statistics/203247/shares-of-householdincome-of-quintiles-in-the-us/. [Accessed: 2020, July 10].

STŘELEC, L., HAMPEL, D., ISSEVER GROCHOVÁ, L. and JANOVÁ, J. 2014. On the measurement of sustainable economic performance. In: Proceedings of $32^{\text {nd }}$ International Conference Mathematical Methods in Economics. Olomouc: Univerzita Palackého v Olomouci.

TŮMA, O. 2017. Očima expertů: Nerovnost v př́ijmech - brzda, či plyn? Peníze.cz. [Online]. Available at: https://www.penize.cz/mzda-a-plat/326153-ocima-expertu-nerovnost-v-prijmech-brzda-ciplyn\#rating326153_85 [Accessed: 2020, July 10].

Contact information

Tamara Kocurová: xkocuro2@mendelu.cz

David Hampel: david.hampel.uso@mendelu.cz 